\title{
PENGUATAN SINERGITAS PENGELOLA PASAR TRADISIONAL DENGAN PEDAGANG DAN MASYARAKAT DI KAWASAN KOTA TERPADU MANDIRI RASAU JAYA MELALUI PENDAMPINGAN KKN-PPM TAHUN 2017
}

\author{
Ngusmanto $^{1 *}$, Nuraini Asriati², Wan Mansor Andi Mulia ${ }^{2}$ \\ ${ }^{1}$ Jurusan Administrasi Publik, Fakultas Ilmu Sosial dan Ilmu Politik, Universitas Tanjungpura, Pontianak, Indonesia \\ ${ }^{2}$ Jurusan Pendidikan Ekonomi Fakultas Keguruan dan Ilmu Pendidikan Universitas Tanjungpura, Pontianak, \\ Indonesia \\ *Penulis Korespondensi: ngusmantountan@gmail.com
}

\begin{abstract}
Abstrak
Penguatan Sinergitas stakeholders Pasar Tradisional melalui Pendampingan KKN-PPM dilatarbelakangi oleh beberapa persoalan mendasar yang saling terkait yaitu pengelola pasar kurang menjalankan tugas pokok dan fungsinya, pegagang pasar belum tertib, pasar dan lingkungannya terlihat kumuh, sebagian pedagang meminjam uang kepada pemilik modal dengan bunga yang tinggi dan minat konsumen berbelanja tergolong masih minim. Oleh karena itu, program ini mempunyai tujuan untuk penguatan manajemen pengelola pasar dan membangun kerjasama yang sinergis antar stakeholders yang menguntungkan. Untuk mewujudkan tujuan, implemetasi kegiatan difokuskan pada pemberdayaan manajamen pengelola pasar dan penguatan kerjasama yang sinergis antar stakeholders. Pemberdayaan manajamen dilakukan melalui diskusi pengurus serta evaluasi tugas pokok dan fungsi serta didampingi serta penetapan bendahara, sedangkan penguatan kerjasama yang sinergis antar stakeholders dilakukan melalui penertiban dan gerakan kebersihan kios dan lapak, dengan dukungan petugas kebersihan, ajakan kepada warga desa rasau Jaya I, II, III dan Rasau Jaya Umum untuk hadir berbelanja dan peringatan hari konsumen melalui berbaga acara lomba dan hiburan yang dapat menarik perhatian publik serta pembentukan koperasi pasar. Hasilnya, pengelola pasar dapat lebih berfungsi, konsumen pasar makin ramai dan pedagang makin meningkat keuntungnnya serta pasar dan lingkungannya terlihat lebih bersih.
\end{abstract}

Kata Kunci : Penguatan, sinergitas, pengelola pasar, pedagang dan masyarakat

\begin{abstract}
There are several reasons why the traditional market should be strengthening through $K K N-P P M$, that is: market management does not function correctly, the trader is not orderly and still borrow money from the loan shark, the market environment looks likes shabby, and the consumer is less interested in going to traditional market. The purpose of KKN-PPM is to establish cooperation between various traditional market stakeholders such as local government as market owner, market management, trader, distributor, and consumer. To achieve these goals, KKN-PPM executes several programs such as program evaluation based on participative mechanism, build the social movement to protect and cleaning the market environment, and launching various event in Consumer Day. The result is that the market management can function correctly, consumer willing to go to traditional market, the trader can get more profit, and market environment is clean and beautiful.
\end{abstract}

Keywords: Strengthening, synergy, market management, traders and community

\section{PENDAhUluan}

Kementerian Tenaga Kerja dan Transmigrasi (Kemenakertran) sejak tahun 2009 telah melaksanakan Program pembangunan Kota Terpadu Mandiri (KTM) sebagai Program pembangunan di kawasan-kawasan transmigrasi di Indonesia dan salah satunya adalah pembangunan KTM Rasau Jaya kabupaten Kubu Raya (KKR) Kalimantan Barat (Kalbar). Pelaksanaan program ini untuk memberikan dukungan dan peningkatkan kemudahan masyarakat di dalam dan di luar wilayah KTM membangun pusat pertumbuhan dan menciptakan sentra-sentra aktivitas bisnis yang menarik para investor, untuk memenuhi kebutuhan dasar, mendorong pertumbuhan ekonomi dan sosial, membuka kesempatan kerja dan berusaha serta peningkatan asesibilitas masyarakat di wilayah transmigrasi dan sekitarnya secara berkelanjutan.

Implementasi dari kebijakan tersebut, khususnya di KTM Rasau Jaya telah berhasil mewujudkan 
beberapa program pembangunan fisik yang terdiri dari: (1) Pembangunan Pusat Bisnis dan Ruang Tunggu Penumpang, (2) Pembangunan Rumah Pintar, (3) Pembangunan Pasar Tradisonal, (4) Pembangunan Himpunan Wirausaga Transmigrasi (HW-Trans), (5) Pembangunan Islamic Centre, (6) Pembangunan Masjid, (7) Pembangunan Asrama Putri Islamic Centre dan (8) Pembangunan Jalan Lingkar Islamic Centre. Pembangunan ini secara fisik tergolong berhasil dan terlihat Megah, sekaligus dapat menjadi kebanggaan KTM Rasau Jaya dan masyarakat transmigrasi. Semua pembangunan fisik tersebut telah diserahkan dari pemerintah pusat melalui Kemenakertran kepada pemerintah daerah KKR dan telah dimanfaatkan sesuai peruntukkannya (Laporan Kepala KTM Rasau Jaya, Tahun 2015).

Persoalan yang muncul sesuai investigasi (Ngusmanto, 2015) pasca penyerahan dan pemanfaatan bangunan, terutama pasar tradisional ditemukan bahwa Kemenakertran (pemerintah) dan Dinas Tenaga Kerja dan Transmigrasi (Disnakertrans) atau Pemerintah Daerah KKR belum melakukan program pembinaan dan pendampingan kepada pengelola pasar serta pengguna kios dan lapak (Pedagang) serta masyarakat konsumen di lokasi Kuliah Kerja Nyata Pembelajaran Pemberdayaan Masyarakat (KKN PPM) Universitas Tanjungpura (UNTAN). Masalah yang ditemukan antara lain: (1) Lingkungan pasar terlihat kotor atau kumuh dan terkesan kurang dikelola dengan baik; (2) Pengelola pasar yang telah dibentuk kurang melaksanakan tugas pokok dan fungsinya; (3) Program kerja pengelola pasar belum banyak yang diimplementasikan; (4) Personil pengelola pasar belum terisi lengkap, khususnya jabatan bendahara; (5) Belum ada laporan tertulis dari pengelola pasar secara rutin (bulanan dan tahunan) kepada ketua Unit Pelaksana Tugas (UPT) KTM Rasau Jaya (laporan kegiatan dan keuangan); (6) Pengguna kios dan lapak atau pedagang belum tertib seperti ada yang memidah-tangankan lapak atau kios kepada orang lain (saudara atau teman) yang bukan kewenangannya, serta berjualan di luar lapak atau di luar gedung pasar yang dapat menimbulkan kecemburuan bagi pengguna lapak yang telah tertib dan mematuhi aturan; (7) Beberapa pedagang memilih berjualan di luar lapak dan kios yang telah ditetapkan, dengan cara membuat lapak baru di dekat pintu masuk; (8) Kantor pengelola pasar belum difungsikan karena dipergunakan oleh pengguna lapak dan kios untuk ibadah sembahyang subuh; (9) Beberapa kelengkapan legalitas kelembagaan, terutama akte notaris, NPWP, dan rekening bank belum ada; (10) Konsumen yang datang ke Pasar Tradisional belum begitu ramai; (11) Sebagian pedagang belum membayar atau beberapa kali menunggak pembayaran sewa harian lapak dan kios sebesar Rp. 4500; serta (12) Sebagian pedagang meminjam uang untuk tambahan modal usaha kepada pemilik modal dengan bunga yang tinggi dan sudah pasti sangat memberatkan pedagang, dengan jasa ratarata sebesar $10 \%$.
Permasalahan yang telah diungkap terjadi karena pembinaan dan pendampingan kepada pengelola pasar, pedagang (pengguna kios dan lapak) serta masyarakat yang belum dilaksanakan oleh pemerintah dan pemerintah KKR pasca penyerahan dan pemanfaatan bangunan pasar. Oleh karena itu, penguatan sinergis pengelola pasar dengan pedagang dan masyarakat dalam memajukan dan memanfaatkan pasar tradisional KTM Rasau Jaya sebagai sentra bisnis menjadi solusi yang tepat untuk menyelesaikan masalah di atas dan dapat menguntungkan stakeholders pasar. Untuk itu, kegiatan KKN PPM difokuskan pada: (1) Pemberdayaan manajamen pengelola pasar dan (2) Penguatan kerjasama yang sinergis antar stakeholders pasar.

\section{BAHAN DAN METODE}

Untuk mengatasi persoalan yang telah dijelaskan maka penguatan sinergitas pengelola pasar tradisional dengan pedagang dan masyarakat di kawasan KTM Rasau Jaya melalui pendampingan KKN-PPM merupakan konsep atau metode yang tepat. (Surayin, 2011) menegaskan bahwa sinergi adalah kerjasama antara orang atau organisasi yang hasil keseluruhannya lebih besar daripada jumlah hasil yang dicapai jika masing-masing bekerja sendiri. Konsep lain yang dirujuk adalah tulisan (Najiyati dan Rahmat, 2011) yang mengartikan sinergi sebagai kombinasi atau paduan unsur atau bagian yang dapat menghasilkan keluaran lebih baik dan lebih besar. Jadi, sinergi merupakan kekuatan untuk mengkombinasikan perspektif-perspektif, sumber daya, dan keahlian dari sekelompok orang atau organisasi.

Mereka yang berinteraksi, biasanya diistilahkan atau dipahami sebagai pemangku kepentingan atau stakeholders. (Budimanta dkk., 2008) menegaskan bahwa stakeholders merupakan individu, sekelompok manusia, komunitas atau masyarakat baik secara keseluruhan maupun secara parsial yang memiliki hubungan serta kepentingan terhadap perusahaan, sedangkan stakeholders menurut (Untung, 2008) adalah semua pihak yang mempunyai keterkaitan atau klaim terhadap perusahaan. Berpijak pada kedua pendapat tersebut maka stakeholder adalah semua pihak yang mempunyai kepentingan dan tanggung jawab terhadap kemajuan atau keberhasilan dan kegagalan organisasi seperti perusahaan atau organisasi bisnis, organisasi pemerintah dan lain sebagainya.

Beberapa konsep sinergi dan stakeholders seperti yang dijelaskan oleh tim KKN PPM diterapkan atau diaplikasikan dalam bentuk pembinaan dan pendampingan, sekaligus dijadikan rujukan untuk menyelesaikan persoalan-persoalan yang muncul pasca penyerahan dan pemanfaatan bangunan pasar tadisional KTM Rasau Jaya. Untuk itu, kegiatan KKN PPM difokuskan pada pemberdayaan manajamen pengelola Pasar Tradional dan penguatan kerjasama yang sinergis antar stakeholders. (Chalid, 
2014) menegaskan bahwa pemberdayaan masyarakat sebagai upaya untuk mentransformasikan segenap potensi pertumbuhan masyarakat menjadi suatu kekuatan nyata, untuk melindungi dan memperjuangkan nilai-nilai dan kepentingan di dalam arena segenap aspek kehidupan. Oleh karena itu, ada beberapa kompetensi yang akan ditranfer oleh tim KKN PPM kepada stakeholders pasar tradisional. (Samuel dan Hasiholan, 2011) menegaskan bahwa ada dua kompetensi yang harus dimiliki oleh kelompok usaha kecil yaitu: (1) Ketrampilan usaha dan kemampuan mengelola keuangan, produksi dan pemasaran; (2) Kemampuan yang mengarah pada kewirausahaan dan berbagai sikap yang diperlukan pengusaha. Kondisi ini menurut (Haryati, 2011) akan menambah ramainya berbagai aktifitas usaha pemberdayaan masyarakat dan kegiatan masyarakat di bidang ekonomi pedesaan.

Berpijak pada permasalahan dan konsep penyelesaian masalah yang telah diungkapkan maka proses kegiatan KKN-PPM ini akan berlangsung selama 3 (tiga) bulan dan dilaksanakan di Desa Rasau Jaya I, II, III dan Umum Kecamatan Rasau Jaya Kabupaten Kubu Raya (KKR). Kegiatan KKN PPM diawali dari persiapan, pelaksanaan. Pendampingan, monitoring dan evaluasi (Monep) serta pelaporan kegiatan dan keuangan. Selanjutnya, untuk menjamin keberlanjutan program maka tim KKN PPM berusaha mendorong dan menyiapkan kader yang mau peduli dengan pasar tradisional. Kegiatan persiapan berisi kegiatan survey lokasi dan pemetaan masalah, melakukan koordinasi dan kerjasama dengan KTM, pengelola pasar, pemerintah Kecamatan Rasau Jaya dan pemerintah desa rasau Jaya I, II, III dan Umum. Dilanjutkan dengan rekruitmen mahasiswa peserta KKN PPM, merencanakan waktu dan tempat pelaksanaan kegiatan di lapangan, merencanakan pembekalan selama 3 hari yang memuat materi ketrampilan usaha, ketrampilan mengelola usaha, ketrampilan manajemen keuangan, administrasi, pemasaran, dan ketrampilan membangun kerjasama yang sinergis antara KTM, pengelola pasar, pedagang dan masyarakat, termasuk dengan lembaga keuangan, khsususnya Bank Rakyat Indonesia (BRI) dan Bank Kalbar. Monev dilakukan untuk mengatasi kendala yang terjadi selama program ini berlangsung. Monev kegiatan KKN PPM dilakukan oleh Tim Monev internal (Tim dari Lembaga Penelitian dan Pengabdian Kepada Masyarakat UNTAN (LPPKM UNTAN) dan monev eksternal yang dilakukan oleh tim dari Direktorat Riset dan Pengabdian Masyarakat (DRPM).

Oleh karena itu, target akhir program KKN PPM adalah manajemen pengelola pasar tradisional dapat melaksanakan tugas pokok dan fungsi serta terciptanya kerjasama yang sinergis antar stakeholders pasar dalam memajukan dan memanfaatan pasar tradisional KTM Rasau Jaya sebagai sentra bisnis yang maju dan berdaya saing, yang menguntungkan pemangku kepentingan (pedagang, masyarakat konsumen dan pengelola pasar) dan lingkungan makin bersih serta konsumen semakin banyak yang berbelanja dan merasa puas.

\section{HASIL DAN PEMBAHASAN}

Implementasi program KKN PPM dengan tema penguatan sinergitas pengelola pasar tradisional dengan pedagang dan masyarakat di kawasan KTM Rasau Jaya melibatkan 35 orang mahasiswa dan didampingi oleh 3 (tiga) orang dosen pembimbing, bermitra dengan: (1) Pengelola pasar tradisional, (2) Unit Pelaksana Tugas (UPT) KTM Rasau Jaya dan (3) Jurusan Ilmu Administrasi Publik FISIP UNTAN. Target group KKN PPM terdiri dari: (1) Pengelola pasar sebanyak 5 orang personil, (2) 95 pedagang pasar (pengguna Lapak dan Kios) serta (3) Konsumen yang berasal dari desa Rasau Jaya I, II, III dan Rasau Jaya umum. Proses kegiatan berlangsung selama 3 (tiga) bulan mulai dari persiapan, pelaksanaan dan pendampingan serta bimbingan, monitoring dan evaluasi serta pelaporan kegiatan dan keuangan.

Implementasi kegiatan dan sekaligus dalam rangka menjawab berbagai persoalan yang terjadi pada pengelola pasar, pengguna kios dan lapak (pedagang) serta masyarakat konsumen maka kegiatan KKN PPM difokuskan pada 2 (dua) luaran utama yaitu pemberdayaan manajamen pengelola pasar tradisional dan penguatan kerjasama yang sinergis antar stakeholders pasar, yang keduanya dapat dijelaskan seperti uraian berikut.

\section{a. Pemberdayaan Manajamen}

Pemberdayaan manajamen oleh tim pelaksana dilakukan melalui : (1) Diskusi antar pengurus yang mengelola pasar tradisional, sekaligus menghadirkan dosen dan ketua kelompok masing-masing lokasi KKN PPM serta ketua UPT KTM Rasau Jaya atau personil yang ditunjuk; (2) Evaluasi tugas pokok dan fungsi dari masing-masing personil pengelola pasar tradisional (Ketua, Sekrataris, Bendahara, Seksi Kebersihan dan Keamanan) untuk mengetahui kendala dan masalah yang mereka hadapi selama ini; (3) Melakukan perenungan untuk menumbuhkan kesadaran akan tugas pokok dan fungsi yang belum dilaksanakan oleh masing-masing personil, sekaligus untuk perbaikan ke depan serta (4) Penetapan bendahara pengelola pasar tradisional definitif.

Selama satu tahun terakhir, diakui oleh ketua dan sekretaris (pengelola pasar) bahwa antar personil pengelola pasar tidak melakukan kegiatan koordinasi atau rapat antar personil pengelola pasar (Ketua, sekretaris, bendahara, seksi kebersihan dan keamanan). Malahan bendahara tidak aktif sama sekali dan sebagian tugasnya dilaksanakan oleh sekretaris, khususnya tugas penagihan uang iuran harian dari pengguna lapak dan kios dan pemberian bukti telah membayar iuran. Ada beberapa alasan mengapa bendahara tidak aktif dalam jangka waktu yang lama 
(lebih dari satu tahun). Alasan tersebut antara lain: (1) Sengaja tidak diperankan; (2) Bendahara memang tidak aktif; dan (3) Bendahara minta ganti, tetapi belum diganti.

Persoalan yang muncul dengan tidak adanya bendara antara lain: (1) Pembukuan dan pelaporan keuangan triwulanan dan atau tahunanan yang seharusnya disampaikan kepada ketua UPT KTM Rasau Jaya menjadi tidak jalan (selalu pihak pemerintah daerah dan wakil pemerintah pusat), (2) Rapat pertanggung jawaban penerimaan dan penggunaan keuangan pengelola pasar, yang sumber dananya berasal dari iuran sewa kios dan lapak (pedagang) belum atau tidak dilaksanakan sama sekali. Hal demikian pernah dikeluhkan oleh manajemen UPT KTM Rasau Jaya. Realitas ini menjadi indikasi bahwa besar penerimaan pengelola pasar dan penggunaan uang peneriman belum diketahui oleh UPT KTM dan ketua pengelola pasar karena data keuangan masih ditangan sekretaris.

Di sisi lain, antar personil juga tidak membangun kerjasama yang sinergis dalam pengelolaan pasar sesuai tugas pokok dan fungsi masing-masing. Selama ini, pelaksanaan tugas pokok dan fungsi lebih banyak dijalankan oleh sekretaris, personil kebersihan dan keamanan, dengan berbagai keterbatasan. Persoalan yang sangat dirasakan oleh pengguna lapak dan kios terkait dengan pelayanan lampu penerangan pasar. Lampu kurang terang dan beberapa lampu putus, tetapi belum diganti oleh pengelola pasar. Lampu penerang pasar yang kurang lebih mengesankan bahwa pasar terasa remang-remang dan bagi mereka yang belum terbiasa lebih mengesankan menyeramkan untuk datang dan berbelanja di pasar. Lampu penerang penting karena pasar tradisional sudah mulai beraktivitas pukul 04,00 dini hari atau dikenal sebagai pasar pagi. Situasi demikian telah diketahui dengan persis oleh pengelola dan tidak segera mendapat pelayanan perbaikan oleh pengelola pasar karena beberapa penyebab antara lain: (1) Untuk menekan biaya listrik bulanan yang tergolong besar. Salah satu caranya mengurangi lampu; dan (2) Biaya yang ada belum mendukung.

Mereka (personil) menerima instentif rata-rata sebesar Rp. 1.000.000,- (satu juta rupiah), khususnya sekretaris, bagian kebersihan dan keamanan. Uang insentif tersebut diambil dari iuran penggunana kios dan lapak, yang rata-rata setiap pedagang membayar kios dan lapak sebesar Rp. 4500; hari. Jika uang ini dikalikan dengan 95 pedagang x 30 hari (satu bulan) maka pengelola pasar dapat memperoleh income atau pendapatan sebesar Rp. 12.825.000 (dua belas juta delapan ratus dua puluh lima ribu rupiah). Potensi penerimaan cukup besar dan dapat dipergunakan untuk membayar insentif kepada semua pengelola pasar (5 personil), membayar listrik, kebersihan dan bahkan bisa melakukan saving. Ketua pengelola pasar memberikan informasi bahwa penerimaan pasar belum dapat mengatasi semua biaya operasional pasar. Untuk itu, besar penerimaan belum dapat mencukupi kebutuhan operasonal pasar.

Pesoalan penting berikutnya bahwa potensi income sulit diwujudkan karena beberapa penyebab yaitu: (1) Sebagian pedagang tidak dapat membayar iuran secara rutin setiap hari; (2) Tidak semua pengguna kios dan lapak (pedagang) berjualan atau membuka lapak dan kios rutin setiap hari, sehingga pembayaran iuran menjadi tidak terbayar dan sebagian dari mereka sulit menagihnya; dan (3) Sebagian pedagang menunggak. Situasi demikian dapat terjadi dan salah satu penyebabnya karena jabatan bendahara tidak ada personilnya. Salah satu tugas utama bendahara adalah menarik dan menagih iuran dari pengguna kios dan lapak. Persoalannya adalah bendahara pasar tidak punya, sehingga penerimaan pengelola pasar selalu tidak mencapai target. Untuk itu, penetapan bendahara definitif menjadi kebutuhan prioritas pengelola pasar.

Pelayanan manajemen pasar yang masih dikeluhkan oleh pedagang (pengguna lapak dan kios) berkaitan dengan pengaduan dan keluhan, tetapi tidak segera mendapat perhatian pengelola pasar. Keluhan mereka antara lain: (1) Ada yang mengeluh kepada pedagang yang tidak tertib; dan (2) Ada yang mengeluh terhadap oknum pedagang yang berjualan di luar lapak yang telah ditentukan, tetapi malahan membuat lapak baru, tidak segera ditertibkan. Untuk memudahkan pelayanan maka Tim KKN PPM berkerjasama dengan pengelola pasar dibantu oleh beberapa pedagang memfungsikan kantor atau sekretariat pengelola pasar. Kantor yang awalnya dipergunakan oleh pedagang untuk sholat subuh, oleh pengelola ditata kembali dan difungsikan menjadi kantor untuk pelayanan kepada pedagang dan pihak lain yang berhubungan seperti UPT KTM Rasau Jaya, Kepala Desa Rasau Jaya I, II, III dan Rasau Jaya Umum, camat, Dinaskertrans dan pihak lainnya, sedangkan ruang untuk sholat disediakan di ruang lain. Adanya kantor pengelola menimbulkan beberapa nilai positif yang dirasakan oleh stakeholders pasar, terutama pedagang antara lain: (1) Pelayanan lebih mudah; (2) Mudah menyampaikan pengaduan; (3) Dokumen administrasi dapat tersipan secara rapi dan aman di kantor dan tidak dibawa pulang oleh sekretaris; dan (4) Pihak lain yang ingin bekerjasama dengan pengelola pasar lebih percaya dan yakin. Demikian juga monitoring dan evaluasi dari pemerintah pusat atau pemerintah daerah akan merasa senang dan bangka akan kemajuan pasar tradisional KTM Rasau Jaya.

Kesulitan dalam penguatan manajemen pengelola pasar dan dihadapi oleh tim KKN PPM terkait dengan tertib administrasi keuangan sebelum kedatangan tim. Tim menemukan bahwa administrasi keuangan belum tertib, khususnya besar penerimaan dan penggunaannya untuk setiap bulannya selama 1 (satu) tahun terakhir. Oleh karena itu, Tim KKN PPM hanya menyarankan kepada pengelola pasar dalam beberapa kali diskusi antara lain: (1) Pengelola pasar harus berusaha secara optimal untuk melakukan tertib administrasi keuangan melalui pencatatan penerimaan 
dan pengeluaran; (2) Pengelola pasar harus membuat laporan penerimaan dan penggunaan keuangan setiap tri wulan dan tahunan kepada UPT KTM Rasau Jaya dan (3) Pengelola pasar wajib memberikan informasi kepada pedagang (Pengguna lapak dan kios) tentang realisasi penerimaan uang iuran dan penggunaannya, setiap perayaan hari konsumen, yang jatuh pada setiap tanggal 23 Agustus. Hal ini penting karena personil pengelola pasar mendapat insentif yang bersumber dari iuran pengguna lapak dan kios pasar. Di sisi lain, pelaporan ini sebagai wujud pertanggung jawaban kepada publik (pedagang dan pemerintah) dan wujud transparansi pengelola pasar tradisional.

Beberapa foto dukumentasi yang terkait dengan pemberdayaan manajemen pengelola pasar seperti sewaktu diskusi, perenungan serta evaluasi tugas pokok dan fungsi personil pengelola pasar serta penetapan bendahara seperti gambar berikut.

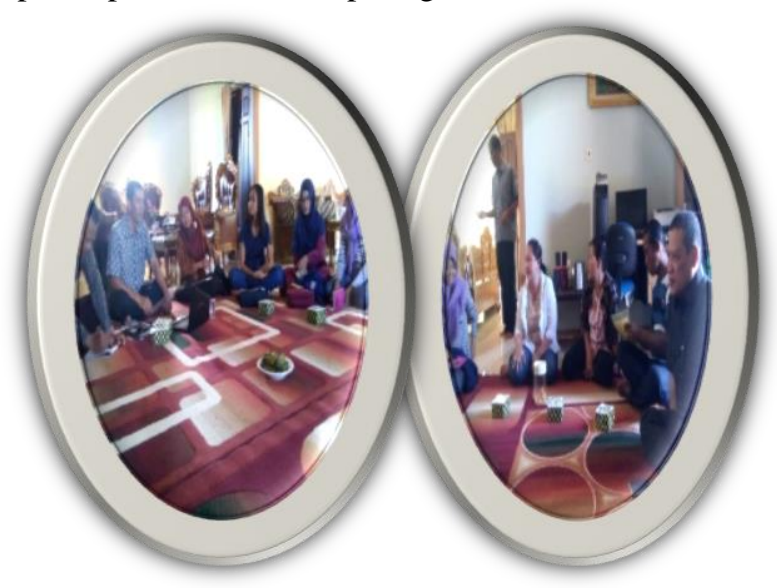

Dokumentasi 1 :

Diskusi Tim KKN PPM dengan Pengelola Pasar Tradisional, 8 Juli 2017

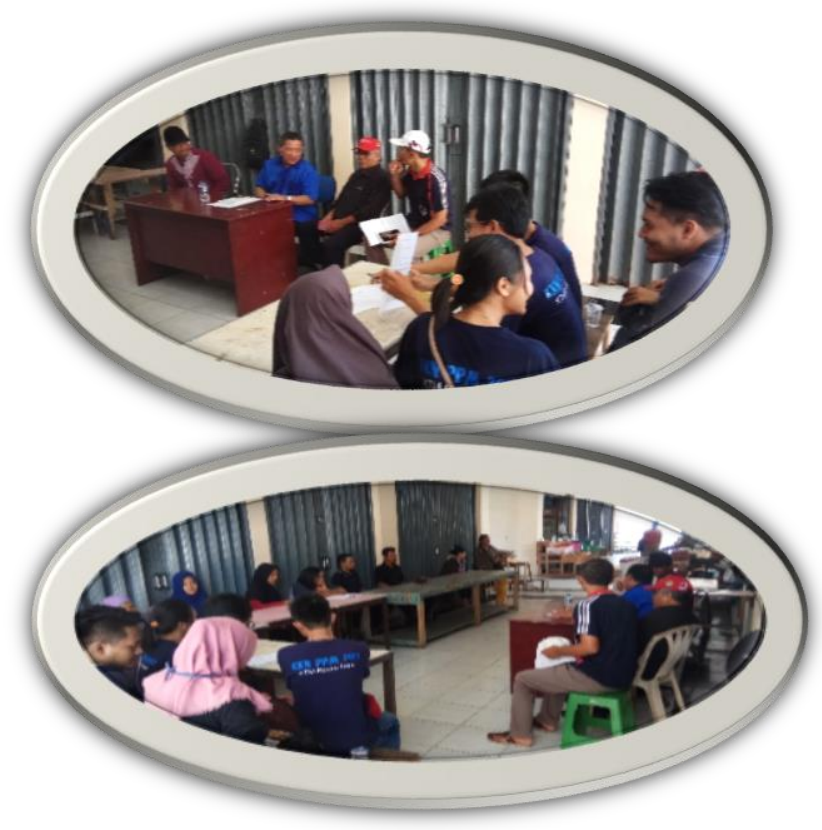

Dokumentasi 2 :

Tim KKN PPM Melakukan Penguatan Manajemen Pengelola Pasar Tradisional KTM Rasau Jaya, 9 Juli 2017
Hasil nyata dari penguatan manajemen pengelola pasar tradisional, disajikan pada Tabel 1.

Tabel 1: Indikator Keberhasilan Penguatan Manajemen Pengelola Pasar Tradisional Tahun 2017

\begin{tabular}{|c|c|c|c|}
\hline No & Indikator & Awal & Akhir \\
\hline \multirow[t]{3}{*}{1} & & Satu Tahun & \\
\hline & Rapat & Terakhir Tidak & Selama KKN \\
\hline & Koordinasi & ada & PPM 3 Kali \\
\hline \multirow[t]{2}{*}{2} & Pelaksanaan & Baru sekretaris & Semua \\
\hline & Tugas & dan Kebersihan & Melaksanakan \\
\hline \multirow[t]{2}{*}{3} & Pelaksanaan & Baru sekretaris & Semua \\
\hline & Fungsi & dan Kebersihan & berfungsi \\
\hline \multirow[t]{2}{*}{4} & Ruang & & Ada dan \\
\hline & Kantor & Tidak ada & fasilitasnya \\
\hline \multirow[t]{2}{*}{5} & & Tidak ada & \\
\hline & Personil & Bendahara & Lengkap \\
\hline \multirow[t]{2}{*}{6} & Kelngkapan & Ada AD/ART & Tambah \\
\hline & Legalitas & dan Stempel & Stempel \\
\hline \multirow[t]{2}{*}{7} & Adm. & & \\
\hline & Keuangan & Tidak ada & Sedang dibuat \\
\hline \multirow[t]{2}{*}{8} & Pelaporan & & \\
\hline & Kegiatan & Tidak ada & Sedang dibuat \\
\hline \multirow[t]{2}{*}{9} & Pelaporan & & \\
\hline & Keuangan & Tidak ada & Sedang dibuat \\
\hline \multirow[t]{2}{*}{10} & Pelayanan & & Lampu Putus \\
\hline & Pengelola & Belum ada & diganti \\
\hline \multirow[t]{2}{*}{11} & Pelayanan & & Mendapat \\
\hline & Pengqduan & Belum ada & Perhatian \\
\hline
\end{tabular}

Sumber: Hasil Kompilasi Data di Laporan Kemajuan KKN PPM, Agustus 2017

Informasi yang disajikan pada Tabel 1 yang menggunakan indikator keberhasilan penguatan manajemen Pengelola Pasar Tradisional Tahun 2017 oleh Tim KKN PPM menunjukkan kemajuan dan atau perubahan yang cukup penting, walaupun baru menggunakan ukuran kualitatif. Hal ini terlihat dari perbandingan posisi awal sebelum program KKN masuk dan sesudah program masuk. Kemajuan dalam penguatan manajemen pengelola akan semakin mantap dalam memajukan pasar dan pelayanan konsumen, apabila ada pendampingan dan terus dimotivasi oleh pihak luar seperti dosen dan mahasiswa, termasuk pemerintah pusat dan daerah. Perlu ditegaskan bahwa pelaksanaan tugas pokok dan fungsi personil pengelola pasar selama ini belum optimal karena mereka merasakan baru mendapat insentif yang diterima ralatif kecil atau belum dapat memenuhi kebutuhan pokok mereka. Persoalan ini dapat diatasi, apabila manajemen penerimaan dan pengeluaran keuangan dikelola dengan baik, transparan dan bertanggung jawab. Langkah demikian akan menumbuhkan kepercayaan pedagang dan ia akan membayar iuran lebih baik, sehingga penerimaan pengelola akan meningkat, sekaligus akan dapat meningkatkan besar insentif yang diterima oleh personil pengelola pasar. 


\section{b. Penguatan Kerjasama yang Sinergis}

Penguatan kerjasama yang sinergis antar stakeholders (Pengelola pasar, Pedagang dan masyarakat konsumen) dilakukan melalui antara lain: (1) Penertiban dan gerakan kebersihan kios dan lapak serta lingkungan pasar, dengan dukungan petugas kebersihan; (2) 3 (tiga) kali pertemuan dengan kelompok warga sebagai calon konsumen; (3) Kunjungan secara door to door ke rumah warga atau calon konsumen selama satu minggu (sebelum hari konsumen) yang tersebar di desa Rasau Jaya I, II, III dan Rasau Jaya Umum; (4) Pemasangan spanduk yang dilakukan oleh mahasiswa peserta KKN PPM; dan (5) Penyebaran brosur yang isi utamanya tentang pasar tradisional. Semua kegiatan yang telah disebutkan berisi ajakan dan himbauan dari mahasiswa KKN PPM kepada calon konsumen untuk hadir dan berbelanja di pasar tradisional. Warga di keempat desa ini juga diberikan informasi bahwa mereka bisa menitipkan produknya untuk di jual di pasar tradisional melalui kerjasama dengan pengguna lapak dan kios. Mereka juga dihimbau untuk mengajak saudara dan teman-temannya yang tinggal di dalam dan di luar KTM Rasau Jaya untuk berbelanja dan membeli produk di pasar tradisional dan menjualnya kembali di desa lain wilayah dan di luar wilayah KTM seperti Desa Pinang Luar dan Pinang Dalam, Desa Teluk Nangka dan Desa Bintang Mas. Beberapa konsumen yang berbelanja di pasar tradidional dan diwawancarai oleh Tim KKN PPM menegaskan dan memberikan informasi bahwa ia berasal dari 4 desa yang telah disebutkan. Ada pula 4 pedagang keliling yang membeli barang di pasar tradisional dan selanjutnya menjualnya kembali di desa pinang luar dan dalam. Fakta ini menjadi indikasi bahwa pasar tradisional makin dikenal dan dijadikan tempat berbelanja oleh konsumen (pelanggan lama) maupun konsumen pendatang baru. Hal demikian juga diakui oleh pedagang pasar, UPT KTM Rasau Jaya dan pengelola pasar tradisional bahwa pembeli atau konsumen pasar bertambah banyak atau semakin ramai.

Tim juga melakukan kegiatan lomba kebersihan dan lomba pembayar iuran terajin. Lomba jenis ini penting dan dapat berpengaruh terhadap kemajuan pasar tradisional. Kebersihan menjadi salah satu kunci kenapa konsumen suka dan termotivasi berbelanja di pasar tradisional, sehingga kebersihan lapak dan kios, oleh Tim KKN dan pengelola pasar dipilih dan dijadikan salah satu jenis lomba penting dan berdampak besar bukan hanya bagi pedagang, melainkan juga ke konsumen dan pengelola pasar. Secara umum, konsumen lebih termotivasi belanja di pasar yang bersih, sedangkan dari sisi pengelola, pasar dan lingkungan yang bersih menjadi indikasi kuat bahwa pengelola pasar mampu mewujudkan pasar tradisional yang bersih dan indah. Pedagang sendiri juga lebih nyaman berjualan di lokasi yang bersih dan sudah pasti bahwa konsumen akan lebih suka berbenja. Akhirnya pedagang dapat untung yang lebih banyak dan pihak lainnya (stakeholders) juga akan merasa nyaman di pasar yang bersih. Selain itu, pasar dan lingkungan yang bersih dapat menghilangkan kesan kumuh dan bau tidak sedap, yang selama ini pernah terjadi di pasar tradisional.

Untuk meningkatkan kerjasama dan memotivasi konsumen datang dan berbelanja di pasar, tim pelaksana KKN PPM bekerjasama dengan pedagang dan pengelola pasar serta mendapat dukungan kepala Dinaskertrans, camat, kepala desa rasau Jaya I, II, III dan rasau jaya umum menyelenggarakan peringatan hari konsumen, yang kebetulan jatuh pada setiap tanggal 13 Agustus. Dalam peringatan hari konsumen, panitia mengadakan berbagai acara dan lomba seperti senam kesehatan dan hiburan, dalam rangka menarik perhatian publik, sekaligus untuk memajukan pasar. Untuk biaya peringatan hari konsumen pasar tradisional diperoleh dengan cara gotong royong antara lain: (1) Tim KKN PPM menanggung biaya orgent tunggal, 1 orang penyanyi dan biaya sound system; (2) Desa Rasau Jaya III menanggung biaya panggung; (3) Kursi dan Tenda dibiayai oleh camat dan pengelola pasar tradisional; (4) Doorprize dibiayai oleh iuran mahasiswa dan dosen pembimbing; (5) Hadiah di tanggung oleh pengelola pasar dan Tim KKN PPM; (6) Semua konsumsi dalam bentuk kue dan makan nasi, termasuk pembuatan tumpeng dibiyai oleh pedagang pasar, dengan cara patungan; (7) Generasi muda Rasau Jaya Umum dan III menyumbang dan mengisi bend Akuistik, serta (8) Rasau Jaya 1 menyumbang instruktur senam sehat.

Selanjutnya dalam rangka merangsang konsumen datang dan berbelanja maka setiap pembeli yang berbelanja di pasar tradional lebih dari Rp. 20.000, mahasiswa KKN PPM akan memberikan kupon undian untuk memperoleh doorprize. Kegiatan demikian berlangsung selama 1 (satu) pekan mulai tanggal 6 - 12 Agustus 2017. Jadi, mereka yang berbelanja 7 hari berturut-turut ya akan mendapat 7 kupon untuk memperebutkan hadiah atau doorprize. Apa isi dari setiap doorprize akan diketahui dan diberikan kepada konsumen pada puncak peringatan hari konsumen tanggal 13 Agustus. Hadiah khusus bagi pembayar iuran sewa kios dan lapak yang paling rajin $(1,2$ dan 3$)$ disediakan oleh pengelola pasar.

Kekurangan modal bagi beberapa pedagang pasar dan agar pedagang terhindar dari ulah pemilik modal yang mengenakan bunga tinggi maka pengelola pasar bersama UPT KTM Rasau Jaya dan perwakilan pedagang membentuk Koperasi Serba Usaha (KSU) Pasar Tradisional KTM Rasau Jaya, yang salah unit usahanya adalah usaha simpan pinjam, dengan modal awal Rp. 5.000.000; (Lima juta rupiah). Modal KSU yang belum besar ini berasal dari bantuan Tim KKN PPM UNTAN. Ketua koperasi terpilih bernama Haryanto dan berasal dari pedagang pasar. KSU Pasar telah memiliki personil yang lengkap dan telah memiliki AD/ART serta buku rek. BRI. Supaya KSU dan pengurus langsung dapat beroperasi maka bantuan modal usaha dari Tim KKN PPM akan dipinjamkan 
kepada 25 orang (dua puluh lima) pedagang dan masing-masing pedagang baru dapat meminjam sebesar Rp. 200.000 (dua ratus ribu rupiah).

Ada beberapa persyaratan yang harus dipenuhi oleh pedagang, untuk dapat meminjam uang di KSU sebagaimana telah dirumuskan dan ditetapkan oleh pengelola KSU Pasar Tradisional. Persyaratan utama untuk dapat meminjam uang di KSU, yang harus dipenuhi oleh pedagang pasar antara lain: (1) Setiap peminjam adalah pedagang pasar tradisional dan telah menjadi anggota koperasi; (2) Telah membayar iuran pokok anggota sebesar Rp. 20.000 (dua puluh ribu rupiah) dibayar satu kali selama menjadi anggota koperasi; (3) Telah membayar iuran wajib setiap bulan sebesar Rp. 5.000; (lima ribu rupiah).

Dokumentasi dalam bentuk foto-foto kegiatan Penguatan kerjasama yang sinergis antar stakeholders, seperti gambar berikut.

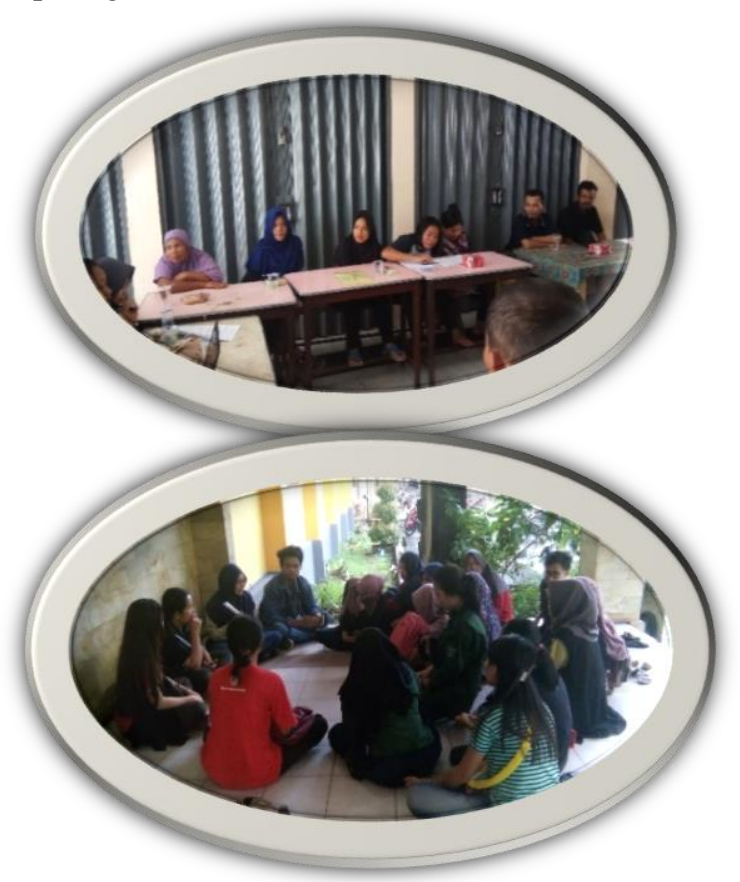

Dokumentasi 3 :

Tim KKN PPM Melakukan Dialog dengan Pengelola Pasar Tradisional, Pedang dan Tokoh masyarakat, Untuk Membangun sinergitas, 15 Juli 2017

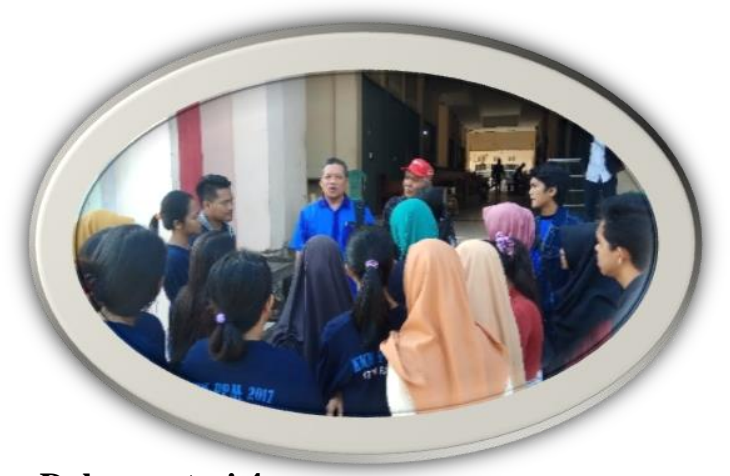

Dokumentasi 4 :

Dosen Pembimbing KKN PPM Melakukan Bimbingan dan Pendampingan Mahasiswa KKN PPM, 17 Juli 2017

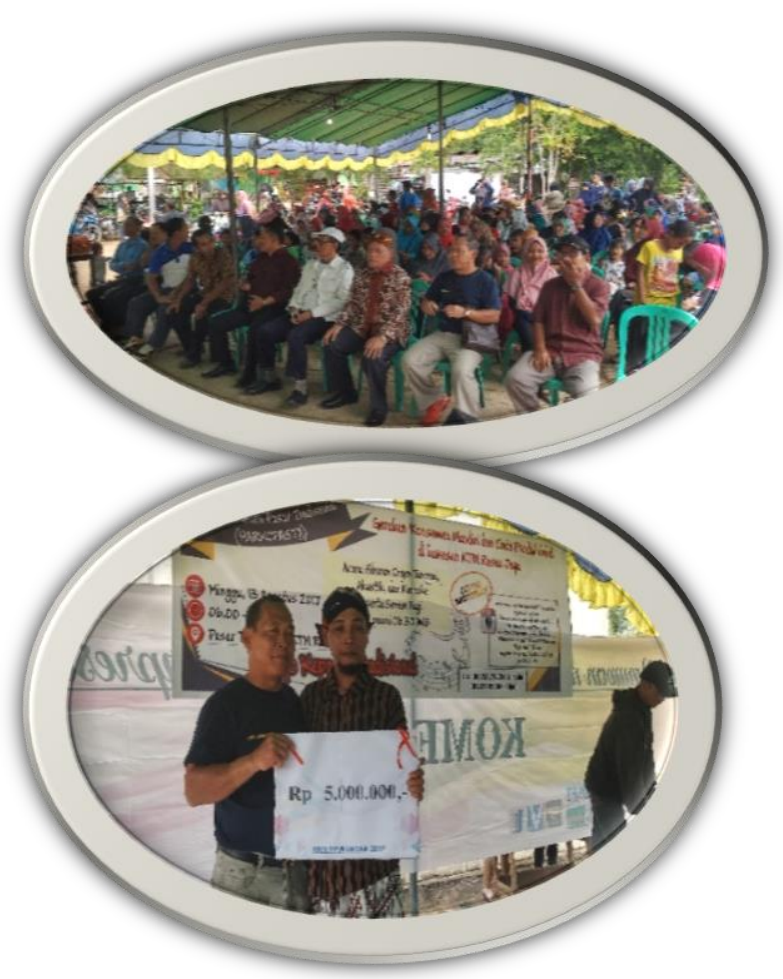

Dokumentasi 5 :

Peringatan Hari Konsumen Pasar Tradisional KTM Rasau Jaya, 13 Agutus 2017

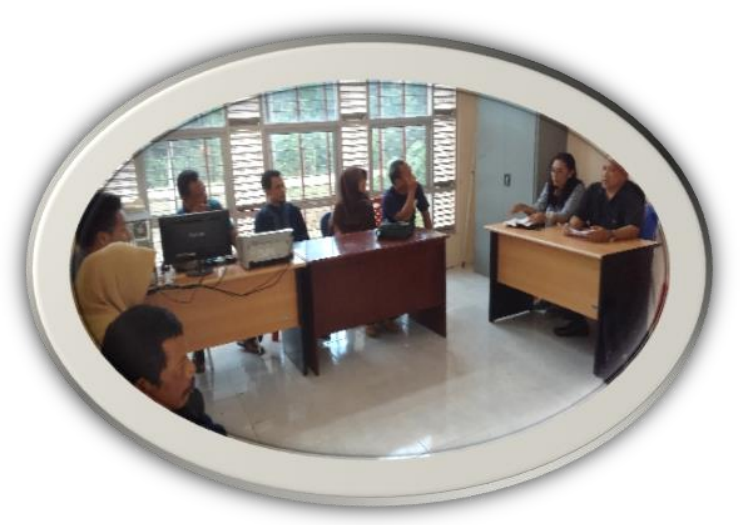

Dokumentasi 6 :

Monitoring dan Evaluasi Internal KKN PPM Oleh LPPKM UNTAN, 21 Juli 2017

Hasil nyata dari Penguatan kerjasama yang sinergis antar stakeholders (Pengelola pasar, Pedagang dan masyarakat konsumen), dalam berbagai aktivitas dan indikatornya, disajikan pada Tabel 2.

Tabel 2: Indikator Keberhasilan Penguatan Kerjasama yang Sinergis Antar Stakeholders Pasar Tahun 2017

\begin{tabular}{clll}
\hline No & \multicolumn{1}{c}{ Indikator } & \multicolumn{1}{c}{ Awal } & \multicolumn{1}{c}{ Akhir } \\
\hline \multirow{2}{*}{1} & Kerjasama & Kurang & $\begin{array}{l}\text { Makin Baik } \\
\text { dan sinergis }\end{array}$ \\
& & Jalan & Bertambah \\
& & & Ramai dan \\
2 & Pengunjung & & Banyak
\end{tabular}




\begin{tabular}{llll}
3 & $\begin{array}{l}\text { Keuntungan } \\
\text { Pedagang }\end{array}$ & Sedang & $\begin{array}{l}\text { Bertambah } \\
\text { Besar }\end{array}$ \\
4 & $\begin{array}{l}\text { Kebersihan } \\
\text { Pasar }\end{array}$ & $\begin{array}{l}\text { Kurang } \\
\text { Tidak ada } \\
5\end{array}$ & $\begin{array}{l}\text { Koperasi Pasar } \\
\text { bersih } \\
\text { Ada }\end{array}$ \\
& Pembayaran & Ada & $\begin{array}{l}\text { Tunggakan } \\
\text { berkurang }\end{array}$ \\
6 & Iuran & Tunggakan & Kurang \\
& Ketertiban & Makin \\
7 & Pedagang & Tertib & Tertib \\
& & Pinjam Ke & \\
& Kebutuhan & Pemilik & Beralih ke \\
8 & Modal & Modal & KSU \\
\hline
\end{tabular}

Sumber: Hasil Kompilasi Data di Laporan Kemajuan KKN PPM, Agustus 2017

Informasi yang disajikan pada Tabel 2 yang menggunakan indikator keberhasilan penguatan kerjasama yang sinergis antar stakeholders Pasar Tradisional Tahun 2017 oleh Tim KKN PPM menunjukkan perkembangan ke arah kemajuan dan atau perubahan yang cukup penting, dengan menggunakan ukuran kualitatif. Hal ini terlihat dari perbandingan posisi awal sebelum program KKN PPM masuk dan sesudah program masuk. Kerjasama antar stakeholders pasar yang sinergis yang selama ini belum jalan, mengalami peningkatan yang signifikan. Hal ini sangat terlihat dengan nyata pada saat penyelenggaraan peringatan hari konsumen. Mereka bau membahu dan gotong rayong sebagai upaya mensukseskan peringatan hari konsumen. Mereka juga bergotong royong dalam upaya mewujudkan pasar tradisional yang bersih dan nyaman, melalui gerakan membersihkan lapak dan kios secara bergotong royong. Gotong royong lainnya sebagai wujud kerjasama yang sinergis antar stakeholders juga terlihat dari penyiapan ruang kantor atau sekretariat pengelola pasar dan penyiapan ruang ibadah sholat.

Hasil penting lain berkaitan dengan minat konsumen yang berbelanja di pasar tradisional semakin meningkat. Hal ini diakui oleh pengelola pasar serta pedagang (pengguna lapak dan kios). Pedagang merasakan ada keuntungan yang meningkat dibandingkan sebelum dan sesudah kedatangan tim KKN PPM UNTAN. Keuntungan meningkat juga makin memperlancar pembayaran iuran sewa lapak dan kios, sekaligus ada penurunan besar tunggakan. Informasi ini disampaikan langsung oleh sekretaris pengelola pasar, yang selama ini melaksanakan tugas pokok bendahara menarik dan atau menerima uang iuran sewa lapak dan kios serta kemajuan dan perbaikan lainnya seperti yang disajikan pada Tabel 2 .

Perlu ditegaskan bahwa mahasiswa KKN PPM bukan hanya mendapat pendampingan dosen pembimbing, melainkan juga diberikan masukan oleh kepala Dinas Tenaga Kerja dan Transmigrasi KKR, Camat, Kepala Desa Rasau Jaya I, II, III dan Rasau Jaya serta pengelola pasar. Selain itu, kegiatan KKN PPM juga dimonev oleh Tim Monev UNTAN dan Tm Pusat. Monev dilakukan dalam rangka perbaikan pelaksanaan program KKN PPM.

Perlu ditegaskan bahwa untuk menjamin keberlanjutan program maka tim pelaksana merancang tindak lanjut sebagai upaya untuk menjamin berkelanjutan pelaksanaan kegiatan pasca program KKN PPM berakhir. Tim pelaksana (Ngusmanto dkk, 2017) dalam hal ini telah melakukan langkah-langkah antisipasi antara lain:

a. Dukungan Kader Penggerak sebagai upaya untuk menjamin kerjasama yang sinergis antar stakeholders pasar

b. Membuat usulan agar Program KKN UNTAN ke depan ditempatkan di KTM Rasau Jaya

c. Dukungan Lembaga Keuangan yang memberikan bantuan modal usaha kepada KSU Pasar Tradisional, dengan harapan bahwa pedagang diuntungkan dari sisi besar angsuran dan kecil bunganya

d. Dukungan Program KTM dan pengelola pasar serta Pemerintah Kecamatan dan pemerintah Desa Rasau Jaya I, II, III serta Rasau Jaya Umum.

Dukungan mereka perlu disenergiskan, agar perkembangan dan atau kemajuan pasar tradisional terus meningkat sebagai sentra bisnis yang menguntungkan stakeholders pasar. Khusus personil pengelola pasar, pengurus KSU pasar serta pedagang (pengguna kios dan lapak) perlu mendapat pendampingan, ataupun setidak-tidaknya ada usaha untuk mengingatkan personil dalam pelaksanaan tugas pokok dan fungsi personil pengelola pasar, pemberian motivasi kepada stakeholders pasar dan kegiatan lain yang berkontribusi pada kemajuan pasar sebagai centra bisnis yang menguntungkan.

\section{KESIMPULAN}

Kesimpulan penting dari pelaksanaan program KKN PPM UNTAN terlihat dari hasil nyata kegiatan lapangan mahasiswa dan dosen pembimbing, yang mendapat dukungan langsung maupun tidak langsung dari stkeholders pasar. Kegiatan KKN PPM di KTM Rasau Jaya tahun 2017 difokuskan pada pemberdayaan manajamen pengelola pasar tradisional dan penguatan kerjasama yang sinergis antar stakeholders antara lain terlihat nyata dari : (1) Pengelola pasar dapat lebih berfungsi dan pelaksanaan tugas pokok berjalan lebih baik, seperti pelayanan akan kebutuhan penerangan bagi pedagang pasar tradisonal serta pelayanan keluhan pedagang yng terkait kebersihan dan ketertiban pedagang; (2) Konsumen pasar makin bertambah ramai yang berasal dari dalam dan luar KTM Rasau Jaya, sehingga pendapatan pedagang (pengguna kios dan lapak) semakin besar dan terus meningkat, sekaligus mereka dapat membayar iuran harian lebih lancar serta (3) Pasar dan lingkungannya terlihat lebih bersih. Di 
sisi lain, kerjasama yang sinergis antar stakeholders pasar dapat memajukan pasar tradisional yang menguntungkan bagi pedagang, konsumen dan pengelola pasar tradisional.

\section{UCAPAN TERIMA KASIH}

Kegiatan KKN PPM dapat dilaksanakan dengan baik dan kedua fokus dapat diwujudkan karena bantuan dan dukungan berbagai pihak, terutama ketua LPPKM UNTAN, pengelola pasar dan mitra lainnya, mahasiswa dan dosen pembimbing lapangan, termasuk penulisan laporan yang harus didukung oleh manajeman pengelola pasar. Ucapan terima kasih juga disampaikan kepada LPM UNIMED yang telah bersedia menerbitkan dan mendanai keberlangsungan jurnal ini. Oleh karena itu, pada kesempatan ini Tim KKN PPM menghaturkan banyak terima kasih kepada semua pihak dan kalangan atas bantuan dan dukungannya. Semoga kegiatan ini menjadi amal sholeh.

\section{DAFTAR PUSTAKA}

Budimanta, Arif. Dkk. (2008). Corporate Social Responsibility Alternatif bagi Pembangunan Indonesia, Jakarta: ICSD, Cetakan Kedua..

Chalid, Pheni, (2014). Teori dan Isu Pembangunan, Jakarta, Universitas Terbuka, Edisi Kesembilan

Haryati, Roebyantho, (2011). Dampak Sosial Ekonomi Program Penanganan Kemiskinan melalui KUBE, Jakarta; P3KS Press

Kepala Kota Terpadu Mandiri, (2015). Laporan Tahun, Kubu Raya, UPT KTM Rasau Jaya

Ngusmanto., (2015). Identifikasi Masalah KTM Rasau Jaya dan Langkah Pemecahan Masalah, Rasau Jaya, UPT KTM Rasau Jaya. dkk, (2017) Laporan Kemajuan KKN $P P M$, Pontianak, LPPKM UNTAN

Najiyati, Sri dan Rahmad, Topo, Susilo. (2011). Sinergitas Instansi Pemerintah Dalam Pembangunan Kota Terpadu Mandiri (The Synergy of Goverment Institutions in The Transmigration Urban Development), Jurnal Ketransmigrasian, 28 (2), pp.113-124

Samuel dan Hasiholan, (2011), peran sektor UKM pada ekonomi Indonesia, http://samuelhasiholan.wordpress.c om/2011/05/12/peran-sektor- ukm-padaekonomi-indonesia/ selasa, 20 November 2012

Surayin, (2011). Kamus Umum Bahasa Indonesia, Bandung, Yrama Widya

Untung, Hendrik, Budi. 2008. Corporate Social Responsibility. Jakarta: Sinar Grafika. 